\title{
Longitudinal variation in the composition of the benthic macroinvertebrate fauna of a typical North coast Jamaican river
}

\author{
Eric. J. Hyslop \& Meshagae Hunte-Brown \\ Department of Life Sciences, University of the West Indies, Mona campus, Kingston 7, Jamaica; \\ eric.hyslop@uwimona.edu.jm,meh27@drexel.edu
}

Received 04-II-2011. C Corrected 08-VII-2011. Accepted 08-VIII-2011.

\begin{abstract}
Benthic macroinvertebrate fauna plays a major role in river ecosystems, especially those of tropical islands. Since there is no information on the distribution of benthic invertebrates along a Jamaican river, we report here on the composition of the benthic fauna of the Buff Bay river, on the Northern coast of Jamaica. A total of 14 samples were collected from five sites, using kick nets and a Surber sampler, between May 1997 and October 1998. We also examined the applicability of the rhithron/potamon model, and some of the premises of the River Continuum Concept (RCC) in relation to the distribution of invertebrate taxa. The results showed a total of 38 taxa of identified invertebrates. A group of dominant taxa, composed mainly of immature stages of insects, occurred at all sites. Two notable characteristics of the river were the absence of a true potamonic fauna and the low representation of the shredder functional feeding group in the community We conclude that, while there was minor variation in the composition of the benthic macroinvertebrate fauna among the sites, this was a response to local conditions within the river system. The characteristics of the community did not conform to either of the models. Rev. Biol. Trop. 60 (1): 291-303. Epub 2012 March 01.
\end{abstract}

Key words: freshwater, invertebrates, community composition, longitudinal zonation, river continuum concept, Caribbean.

A major question in freshwater research is whether the ecological models developed for temperate streams apply equally well to their tropical counterparts (Boulton et al. 2008). Uncritical extrapolation of temperate models of ecosystem functioning to the tropical situation could lead to a weak foundation for future research and management decisions (Covich 1988). There is the paucity of information on tropical, as opposed to temperate, freshwater systems (Rundle et al. 1993). Jackson \& Sweeny (1995) point out that the type of data that is often needed for tropical systems is of a descriptive nature. Only once this basic information is established can tropical freshwater systems be viewed in a more holistic fashion.

Attempts to understand the distribution of benthic macroinvertebrates in rivers have lead to a number of hypotheses as to the important defining factors involved. Illies \& Botosaneanu, (1963) cited the combination of physical conditions in the river as being responsible for defining the fauna and suggested the existence of two main faunally discrete regions: rhithron and potamon. The ideas of Vanotte et al. (1980) are based on a model of processing of allochthonous organic input and view the distribution of invertebrates as being influenced by their functional role in this process. There are doubts about the applicability of the latter concept, which was largely conceived in relation to temperate streams, and to tropical rivers in general (Boulton et al. 2008). Other studies (Statzner \& Higler 1985, Statzner et al. 1988) have cited hydraulic stress as a determining factor, 
but this was not found to vary in a predictable fashion along the length of the river.

Studies carried out on Caribbean streams have shown the existence of faunally distinct zones which were defined by temperature (Harrison \& Rankin 1976), and substrate composition/flow pattern (Hynes 1971).

Recent deposits of calcium carbonate dominate the bedrock of Jamaica although there is a central area, the Blue and John Crow Mountains, composed of volcanic rock that overlies them (Porter et al. 1982). Many rivers on the Eastern side of the island arise from this watershed. Rivers which enter the sea on the North coast of the island, contrast to those on the South coast in that they tend to be fairly precipitous in their gradient, turbulent, well oxygenated, and lacking in a significant flood plain. The South Coast Rivers are often of higher stream order (greater channel width) and tend to meander through a flood plain before entering the sea. Nevertheless, freshwater systems in Jamaica are particularly poorly studied.

Boon et al. (1986) in an examination of the macroinvertebrate fauna of several rivers in the Blue Mountains of Jamaica noted that the community was species poor, and dominated by insects. Data collection in their study was confined to the upper regions of several rivers. No study has examined the Jamaican macroinvertebrate fauna from a longitudinal perspective i.e., how composition changes along the length of the river from source to mouth; although this topic has been assessed by Turner et al. (2008) in Trinidad, who found significant changes in longitudinal composition of benthic macroinvertebrates in streams impacted by agricultural and urban activities as compared to pristine streams.

This paper provides a description of the taxonomic composition of benthic macroinvertebrates (BMI) collected over an extended period from five stations along the length of Buff Bay River, a typical Jamaican North coast river. We also examined these data for evidence of longitudinal changes in composition and look at the proportions of different functional feeding groups (FFG's) along the river.

\section{MATERIALS AND METHODS}

Description of location and sites: The Buff Bay river is fairly typical of a North coast Jamaican river in that it is a fourth order stream which rises at an altitude greater than $1000 \mathrm{~m}$ above sea level in the Blue Mountains, and runs a fairly short course $(23 \mathrm{~km})$ to the sea at Buff Bay town. The watershed is described by Gupta (1975) as hilly with a steeply demarcated narrow riverine plain that fans out at the river mouth. The river drainage receives an annual rainfall of $230-380 \mathrm{~cm}$, although intermittent cold fronts can result in $25-33 \mathrm{~cm}$ per day for periods of a few days (Gupta 1975). The area fringing the river supports minimal human habitation and limited small scale agricultural land use. Five sites approximately equidistant from one another along the length of the river

TABLE 1

Characteristics of sampling sites on Buff Bay River

\begin{tabular}{|c|c|c|c|c|c|}
\hline Site Name \&Number & Cascade 1 & Spring Hill 2 & Mullet Hall 3 & Rose Hall 4 & Buff Bay 5 \\
\hline Approx. Altitude (m) & 1000 & 400 & 360 & 200 & 0 \\
\hline Land use & None & Coffee & Low density urban & Low density urban & Urban \\
\hline Vegetation Cover & $\begin{array}{l}\text { Extensive } \\
70 \% \text { cover }\end{array}$ & $\begin{array}{l}\text { Marginal } \\
20 \% \text { cover }\end{array}$ & $\begin{array}{l}\text { Marginal } \\
5 \% \text { cover }\end{array}$ & $\begin{array}{l}\text { Marginal } \\
2 \% \text { cover }\end{array}$ & Lacking \\
\hline Approx. Channel width (m) & 2 & 5 & 7 & 10 & 20 \\
\hline Flow pattern & $\mathrm{R} / \mathrm{P}$ & $\mathrm{R} / \mathrm{P}$ & $\mathrm{R} / \mathrm{P}$ & $\mathrm{R} / \mathrm{P}$ & Mainly R \\
\hline Substrate Characteristics & $\mathrm{B}, \mathrm{S}$ & $\mathrm{B}, \mathrm{S}, \mathrm{G}, \mathrm{Cs}$ & $\mathrm{B}, \mathrm{S}, \mathrm{G}, \mathrm{Cs}$ & $\mathrm{B}, \mathrm{S}, \mathrm{G}, \mathrm{Cs}$ & $\mathrm{B}, \mathrm{S}, \mathrm{G}, \mathrm{Cs}$ \\
\hline Grid reference & $18^{\circ} 05^{\prime} \mathrm{N}-76^{\circ} 41^{\prime} \mathrm{W}$ & $18^{\circ} 06^{\prime} \mathrm{N}-76^{\circ} 41^{\prime} \mathrm{W}$ & $18^{\circ} 08^{\prime} \mathrm{N}-76^{\circ} 40^{\prime} \mathrm{W}$ & $18^{\circ} 12^{\prime} \mathrm{N}-76^{\circ} 39^{\prime} \mathrm{W}$ & $18^{\circ} 14^{\prime} \mathrm{N}-76^{\circ} 39^{\prime} \mathrm{W}$ \\
\hline
\end{tabular}

$\mathrm{R} / \mathrm{P}=$ riffle/pool alternation substrate, $\mathrm{B}=$ boulders, $\mathrm{S}=$ stones, $\mathrm{G}=$ gravel, $\mathrm{Cs}=$ coarse sand. 
were chosen to study and their characteristics are outlined briefly in Table 1 .

Physicochemical sampling: Dissolved oxygen (YSI 5525 DO meter); temperature, conductivity, and $\mathrm{pH}$ (Extech Oyster combined meter) were estimated monthly at all sites. In addition $25 \mathrm{~mL}$ water samples were collected from all sites and preserved in chloroform to use for analysis of nitrate and phosphate levels. These were later read in the lab using a Technicon Autoanalyser II, single-channel colorimeter. This was done on five occasions over a five month period in the middle of the study.

Macroinvertebrate sampling and analytic methods: 14 samples of benthic macroinvertebrates were collected at approximately monthly intervals (except when this was prevented by the river running in spate). Sampling was conducted between May 1997 and October 1998, a total period of 17 months. Two sampling techniques were employed to obtain qualitative benthic macroinvertebrates samples. For all months, where conditions permitted, two min kick samples were taken with standard kick nets $(900 \mu \mathrm{m}$ mesh). Organisms were also collected from beneath stones or from within in-stream vegetation using this net, or in the case of rocks, by hand. In addition, two min Surber samples $(30 \mathrm{~cm}$ frame size with $900 \mu \mathrm{m}$ mesh) were taken four times from each site during the study period. Invertebrates were placed in labelled containers of $10 \%$ formalin and transported to the laboratory for identification. The intention was to collect specimens of all taxa present at a particular site.

For community composition qualitative analysis, samples from all techniques were pooled, and a comparison of the invertebrate community composition at the five sites was done by calculation of monthly Jaccard Community Coefficients (JCC) based on the presence/absence of taxa in the samples.

$$
\mathrm{JCC}=\mathrm{c} /(\mathrm{a}=\mathrm{b}-\mathrm{c})
$$

Where $\mathrm{a}=$ number of taxa at site one

$\mathrm{b}=$ number of taxa at site two

$\mathrm{c}=$ number of taxa common to sites one and two.

In addition, quantitative data were generated from the Surber samples. These were used to calculate Percentage Community Composition (PSC).

$$
\mathrm{PSC}=100-\left[0.5 \Sigma\left(\mathrm{a}-\mathrm{a}^{\prime}\right)\right]
$$

Where $\mathrm{a}=$ proportion of species a at site one $\mathrm{a}^{\prime}=$ proportion of species a at site two.

Identification was carried out to the level of genus where this was possible using the following sources: Merrit \& Cummins (1996) (general insects), Thorpe \& Covich (2001) (general invertebrates), Thompson (2004) (Gastropoda), Chace \& Hobbs (1969) (Decapoda), Peters (1971) (Leptophlebiidae), Gonzalez-Lazo \& Salves (2007) (Baetidae), Edmunds (1984) (other Ephemeroptera), Botosaneanu (1998) pers. comm. (Trichoptera), Spangler (1998) pers. comm. (Coleoptera). Specimens of all invertebrate taxa are held in the collections in the Department of Life Sciences, University of The West Indies, Jamaica and by the Institute of Jamaica.

Assignment of taxa to functional feeding groups (FFGs) was based on the classifications used by Merrit \& Cummins (1996), Graca et al. (2001) and Tomanova et al. (2006). As pointed out by Tomanova et al. (2006) in studies of tropical freshwater invertebrates, there is often some uncertainty about the correct FFG categorization of a taxon which may not necessarily correspond to that of the equivalent temperate species. In this study we classified FFG's according to published information on tropical taxa when possible, and when this was not possible, based our classification on examination of the mouthparts and/or the known microhabitat of the taxon. 


\section{RESULTS}

Perusal of the mean values for the physicochemical parameters (Table 2) indicated that at all sites dissolved oxygen levels were high, and nitrate and phosphate levels were low, indicating little, if any, organic or agricultural contamination in the river. One-way ANOVA and subsequent post hoc testing of the conductivity data indicated that the mean value was significantly $(p<0.005)$ lower at site one. Similarly mean temperature was lower $(\mathrm{p}<0.05)$ at represented. In all but one case, these were found at most sites. Also notable is the apparent absence of gastropods from site one and of odonates from site five; 20 taxa, occur at all sites: Dero, Fallceon, Caenis, Borinquena, Smicridea minima, Nectopsyche, Helicopsyche, Elmis filifomis, Phaenoceros clavicornis, Rhagovelia tayloriella, Prosimulium and Dolchiopus. With the exception of one oligochaete, all were insects.

Using the percentage of the total number of occurrences of macroinvertebrates as an

TABLE 2

Mean values of physico-chemical parameters from five sampling sites on Buff Bay River, Jamaica

\begin{tabular}{|c|c|c|c|c|c|}
\hline $\begin{array}{c}\text { Site } \\
\text { Variable }\end{array}$ & 1 & 2 & 3 & 4 & 5 \\
\hline Temperature ${ }^{\circ} \mathrm{C}$ & 19.5 & 21.0 & 22.3 & 23.2 & 24.2 \\
\hline Conductivity $\mu \mathrm{S} / \mathrm{cm}$ & 234 & 334 & 296 & 316 & 328 \\
\hline Dissolved Oxygen mg/L & 6.0 & 6.7 & 6.2 & 6.3 & 5.4 \\
\hline $\mathrm{pH}$ & 8.5 & 8.3 & 8.3 & 8.3 & 8.3 \\
\hline Nitrate ppb & 31.5 & 17.5 & 13.5 & 11.5 & 10 \\
\hline Phosphate ppb & 14 & 3 & 7 & 6 & 4 \\
\hline Flow rate $\mathrm{m} / \mathrm{sec}$ & 0.2 & 0.25 & 0.31 & 0.25 & 0.25 \\
\hline
\end{tabular}

All means $n=14$ except nitrate and phosphate values where $n=5$.

site one than the other four sites. $\mathrm{pH}$ (mean 8.4) was constant in the mildly alkaline range through all five sites.

Table 3 gives a complete list of the 38 taxa of the benthic macroinvertebrates collected at all sites during the study period, and the percentage of the total number of occurrences per taxon are shown for each site. In addition, this table gives an indication of the importance/ prevalence of a particular taxon by expressing in the last column, the total number of occurrences of that taxon relative to the overall total number of occurrences of all BMI taxa during the sampling period. An occurrence is defined as finding at least one individual of a particular taxon on a particular sampling occasion.

It is worth noting the importance of caddis larva (Trichoptera) in the benthic macroinvertebrate community with eight families indication of abundance, it is possible to identify dominant species. If the criterion of dominance is set arbitrarily at 3\% then 15 taxa can be described as dominant: Fallceon, Borinquena, Enallagma, Orthemis ferruginia, Smicridia jamaicensis, S.minima, Nectopsyche, Helicopsyche, Phyllocius farri, Psphenops, E. filifomis, $P$. clavicornis, $R$. tayloriella, Prosimulium and Thiara granifera. At the 5\% level of occurrences only seven of these taxa would qualify.

Dominant taxa do not necessarily occur at all sites. The following taxa are present at all sites and account for $>3 \%$ of occurrences: Fallceon, Borinquena, S. minima, Nectopsyche, Helicopsyche, E. filifomis, P. clavicornis, R. tayloriella and Prosimulium. With a dominance criterion of $>5 \%$ of total occurrences, then four core taxa remain, all immature insects: Borinquena, S. minima, Nectopsyche and E. filifomis. 


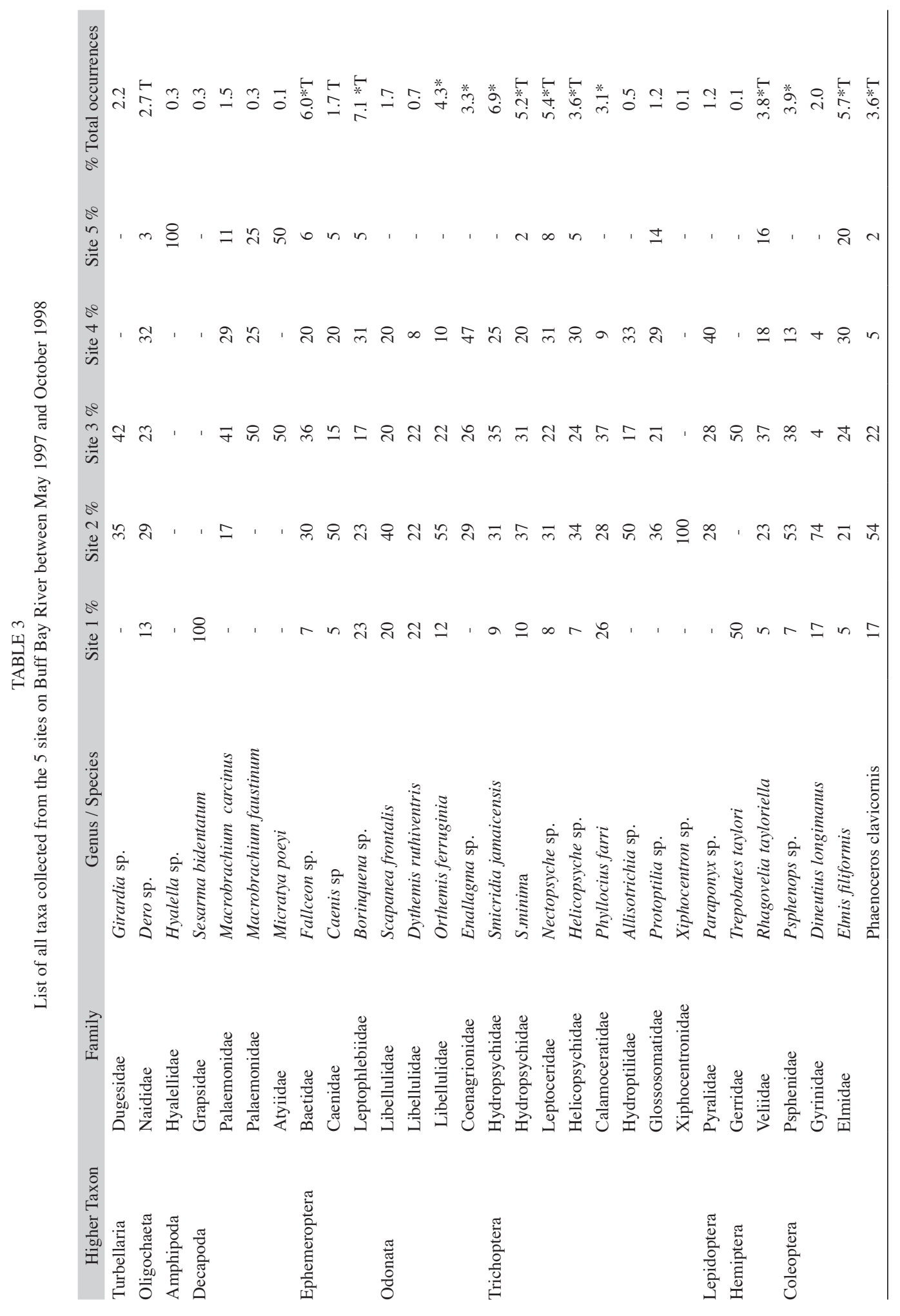




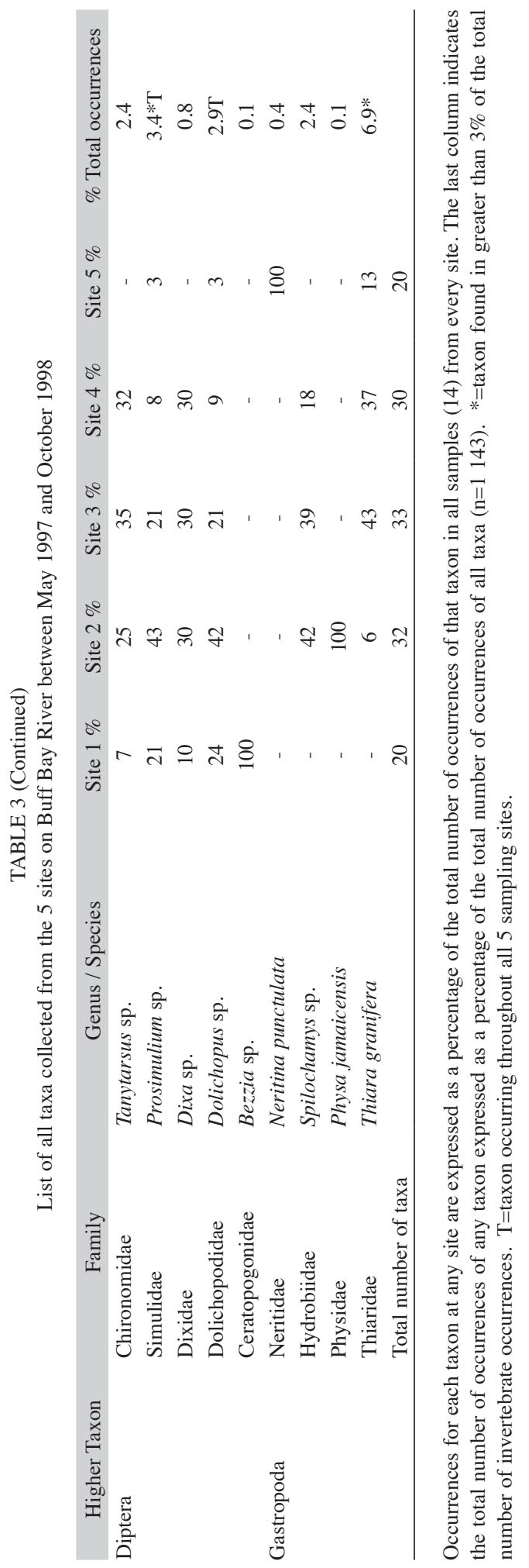

Table 4 shows a matrix of mean values for Jaccard Community Coefficients, and the mean percentage similarity indices for the five sites sampled can be also seen (Table 5). The JCC values indicate the lowest overlap in macroinvertebrate community composition between site five and the other sites, with relatively high values of overlap between sites one-four. At all sites overlap is $>40 \%$. Table 5 reflects similar trends, with the greatest similarity amongst sites two, three and four and the least between sites two and five, and one and four, respectively. Overall site five, due to the low occurrence of insects and a preponderance of shrimps and molluscs, appears least similar to the other sites.

The total number of taxa which can be assigned to each functional feeding group at five sites is shown as a percentage in figure 1 . It is clear that the macroinvertebrate community is dominated by taxa in the collector/ gatherer functional feeding group, as this category makes up 40-50\% of the taxa at all sites. Predators dominate to a lesser extent at sites one-four, but not at site five. The remaining

TABLE 4

Mean values for Jaccard Community Coefficients based on qualitative monthly samples from five sites on Buff Bay River, Jamaica

\begin{tabular}{|c|c|c|c|c|c|}
\hline Site & 1 & 2 & 3 & 4 & 5 \\
\hline 1 & & 61 & 58 & 62 & 42 \\
\hline 2 & & & 85 & 85 & 41 \\
\hline 3 & & & & 94 & 51 \\
\hline 4 & & & & & 51 \\
\hline
\end{tabular}

TABLE 5

Percentage Similarity Coefficients based on quantitative data from 40 Surber samples from five sites on Buff Bay River, Jamaica

\begin{tabular}{cccccc} 
Site & 1 & 2 & 3 & 4 & 5 \\
1 & & 69.4 & 59.0 & 53.7 & 56.1 \\
2 & & & 72.7 & 66.5 & 48.9 \\
3 & & & & 79.2 & 62.8 \\
4 & & & & & 65.3 \\
\hline
\end{tabular}




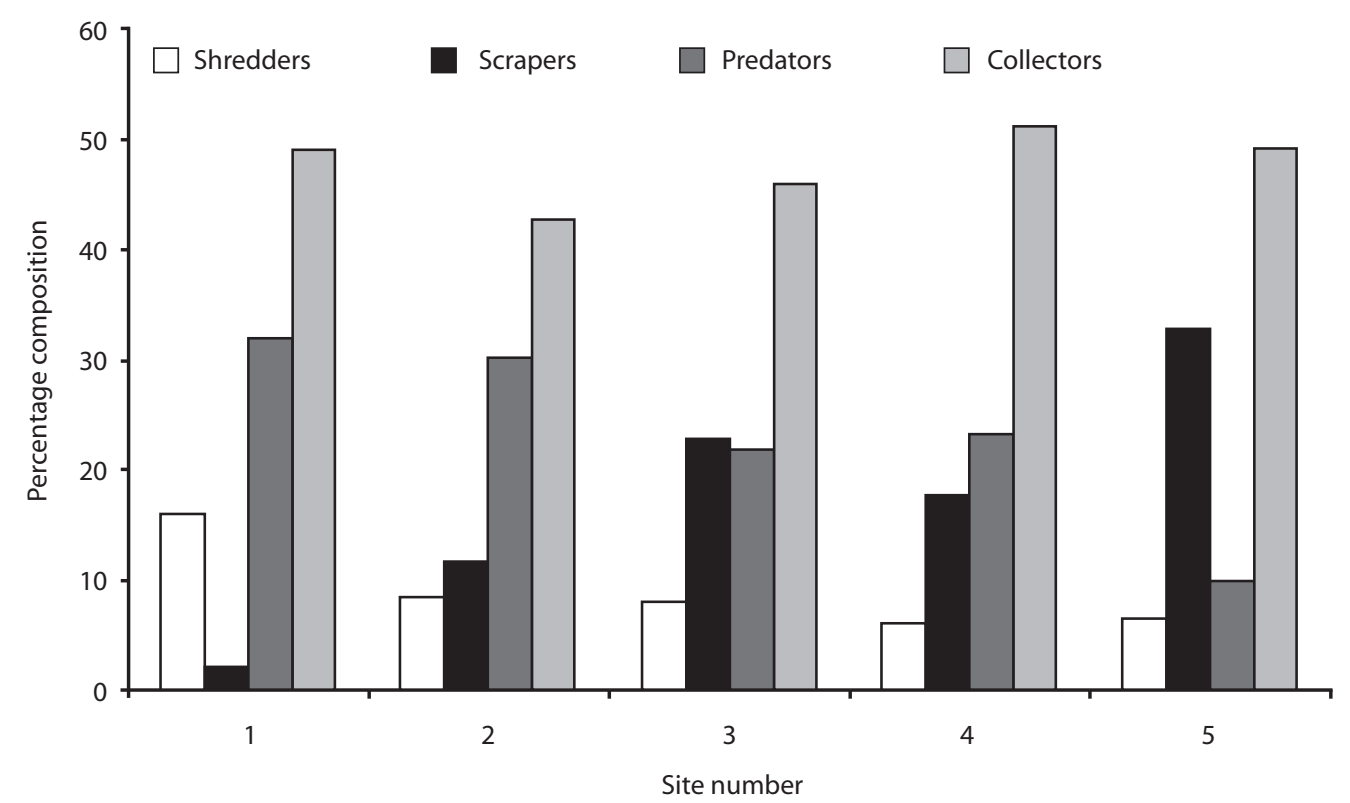

Fig. 1. Percentage of taxa classified into functional feeding groups from five sites on Buff Bay River.

three FFG's are of approximately equivalent importance at all sites.

Using quantitative data from the Surber samples, FFG composition based upon number of individuals sampled is shown in figure 2. It is evident that throughout the river collectors form the dominant FFG with predators and/or scrapers. The importance of shredders based on number of individuals, is greatest at the head of the river, but is never very high at any site.

\section{DISCUSSION}

The Buff Bay River appears to be relatively homogeneous in the measured physicochemical characteristics throughout its length. The main differences among the sites are significantly lower temperature and conductivity at site one. Lower water temperature is due to the effect of air temperature/altitude and greater vegetation cover which shades much of the stream at this site. The lower conductivity may reflect the predominance of volcanic bedrock at site one which is supplanted downstream by calcium carbonate.
Examination of the taxonomic list of benthic macroinvertebrates indicates the presence of relatively few taxa (38) although further detailed taxonomic analysis would undoubtedly boost this total. Most families are represented by a single species or genus, which contrasts to the situation in continental tropical rivers where there has been more time for speciation (Stout \& Vandermeer 1975, Lake et al.1994). It is estimated that most of Jamaica was submerged or emerged only a few meters above sea level until the mid Miocene (Buskirk 1985) and that the uplifting of the Blue Mountains occurred five-ten mya (Comer 1974).

12 taxa occur at all sites, although it is clear that there were differences between site one and site five and the other three sites. These include the absence of all snail taxa from site one as well as shrimps (Macrobrachium spp. and Micratya poeyi). Previous studies by Hunte $(1978,1979)$ and Barnish (1984) noted the two species of Macrobrachium were found to occur at all altitudes whereas $M$. poeyi was restricted to the lower reaches of high altitude turbulent streams in moderate to fast flowing 


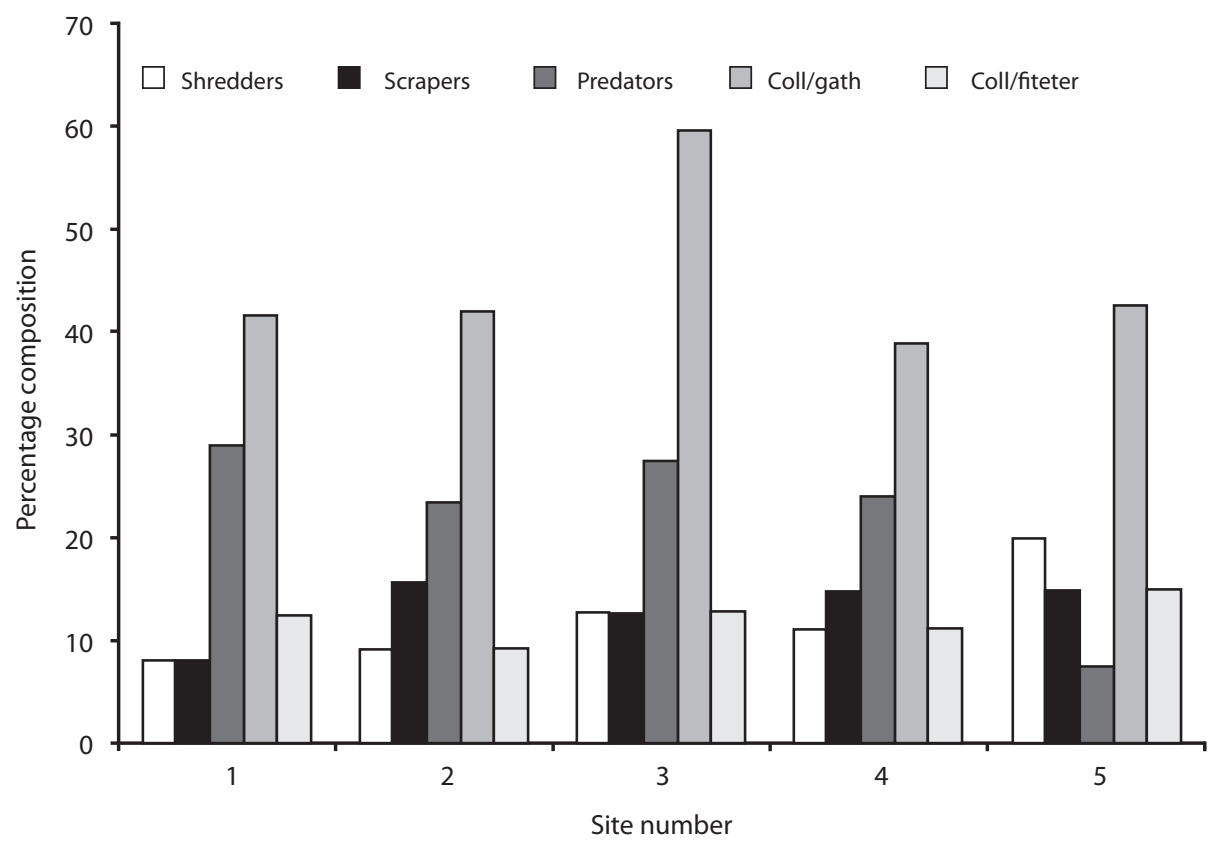

Fig. 2. Percentage composition of functional feeding groups at five sites on the Buff Bay River based on numbers of individuals in 40 quantitative Surber samples.

water. Decapod crustaceans are generally more diverse in tropical streams (Bass 2003) and are considered important components of food webs in tropical stream (March \& Pringle 2003). Due to the nature of the sampling techniques used in this study, which were designed to sample benthic organisms, their taxonomic composition may be underrepresented. March et al. (2001) found greater densities of decapod shrimps over insects in the upper reaches of a Puerto Rican stream but our results concur with Boon et al. (1986) in the predominance of insects. Exclusively found at site one, is the freshwater crab Sesarma bidentatum. There are several non-marine crab species belonging to this family which occur in Jamaica (Hartnoll 1964). At least one species, $S$. bidentatum, is commonly associated with rivers in the Eastern half of the island and several new species have been described in recent years (Schubart et al. 1998).

Insects predominate in the invertebrate communities of sites one-four but were largely absent from site five with only $50 \%$ of the insect taxa occurring elsewhere in the river being found there. Particularly notable is the absence of odonates, often considered to be among the major invertebrate predators of freshwater stream communities (Moss 2010). The absence of Enallagma may be a consequence of the lack of in-stream or marginal vegetation at site five, since this genus is almost exclusively associated with this microhabitat. Boon et al. (1986) made the comment that the lack of in-stream vegetation in Jamaican rivers that they studied was a major factor contributing to low taxonomic richness of the invertebrate communities.

Neritina punctulata occurs at site five only. This species, which is marine in origin, has been shown to ascend rivers and has been found at elevations up to $900 \mathrm{~m}$ in rivers of other Caribbean islands, with a recorded water temperature range between 19.7 to $25.6^{\circ} \mathrm{C}$ (Starmuhlner 1984). N. punctulata has been collected throughout the length of several other Jamaican North coast rivers in close proximity to the Buff Bay River (pers. obs.). The species, 
locally known as "bussu", is of some importance, as it is harvested as a source of food, a process which generates low level income for local fishers. Hyallela, another taxon with marine affinities, also occurs exclusively at site five. Proximity to the sea and the lack of significant in-stream vegetation may modulate against certain taxa at site five, and the community here has a more marine-related composition. The total number of invertebrate taxa collected from sites one and five is lower than the other three sites (Table 3). Lower temperature at site one may exclude certain taxa. Jacobsen et al. (1997) demonstrated a positive relationship between number of insect taxa and maximum temperature. Most species that dominate the community occur at all sites. Exceptions to this are $S$. jamaicensis, $O$. ferruginia and Psphenops sp., all of which are juvenile stages of insects absent from site five. $S$. jamaicensis was observed to be omnipresent in the upper reaches of those Jamaican Blue Mountain streams studied by Boon et al. (1986). T. granifera is considered a dominant but was absent from site one.

This species can be classed as invasive; it was introduced into Jamaican rivers probably in the 1990's (Hyslop 2003) and has spread through most river systems in the island possibly displacing a native thiarid Hemisinus lineolatus in the process. There is a well documented record of $T$. granifera displacing native snails in other Caribbean countries (Pointier 2001). Chaniotis et al. (1980) set the lower temperature limits for $T$. granifera in Puerto Rico at $22^{\circ} \mathrm{C}$, which could account for its absence from site one. The other thiarid species, found in Buff Bay River, Melanoides tuberculata, is also an introduced species in Jamaican rivers but is generally not so widespread as T. granifera (Hyslop 2003).

Illies \& Botosaneanu (1963) had proposed a number of subdivisions of a typical river system based upon both physico-chemical characteristics and community composition. Chief among these was the existence of an upper temperature-limited rhithron and a lower oxygen-limited potamon. Both subsections were expected to support distinct invertebrate faunas. In the Caribbean context, both Hynes (1971) in Trinidad, and Harrison \& Rankin (1976) in St. Vincent had examined the applicability of these ideas. Neither set of findings gave strong support for the concept. Hynes (1971) observed addition and replacement of macroinvertebrate taxa in the lowest section of the river, attributing these differences in faunal composition to differences in substrate composition. Harrison \& Rankin (1976) proposed the existence of a "pseudorhithron" with a limiting temperature of $23^{\circ} \mathrm{C}$ in the upper reaches of St. Vincent streams with a stenothermal restricted component in the invertebrate fauna.

The findings presented here for Buff Bay River, Jamaica do not support the existence of a rhithron/potamon split. Although there are significant differences in mean temperature and conductivity at site one, other physicochemical characteristics do not differ, and there is a broadly similar macroinvertebrate community at all sites. Only certain taxa are absent, and unique taxa added at the top (grapsid crabs, Bezzia sp.), and at the bottom (Neritina punctulata, Hyallela sp.), of the river. Baptista et al. (2001), in a longitudinal study of invertebrate community composition of a Brazilian river, demonstrated a faunal division between the upper river (stream orders one-four) which had erosional processes dominating and features which aided in retention of allochthonous material, and a lower river (stream orders fivesix) with depositional processes, less available leaf litter and a sand or silt substrate. Buff Bay River, ultimately a fourth order stream, would correspond to the "upper" part of the river in terms of faunal composition. Several authors have shown that change in gradient is responsible for the transition from erosional to depositional substrate (Sheldon \& Haick 1981, Statzner et al. 1988). The lack of a true potamon with depositional substrate and lowered dissolved oxygen which would necessitate an invertebrate fauna preadapted to those conditions precludes any major faunal composition shift in the Buff Bay River as demonstrated by Baptista et al. (2001). This results from the 
short length and precipitous gradient of the Buff Bay River, which homogenizes physicchemical conditions, particularly flow patterns and substrate composition, along the river. Baptista et al. (2001) also noted species and genus replacement between the two regions. There is little evidence of taxonomic replacement in Buff Bay River as almost all families are represented by a single species which occurs at most sites.

The River Continuum Concept (RCC) as proposed by Vanotte et al. (1980) views the stream in the context of energy transfer and emphasises the importance of benthic macroinvertebrates as agents in this transfer process. Energy in the form of large particles (often leaves of terrestrial vegetation) also known as coarse particulate organic material $(\mathrm{CPOM})$ enters the upper reaches of the stream and is transformed as it passes downstream through the action of invertebrates. Vanotte et al. (1980) envisaged a role for different Functional Feeding Groups (FFG's) of invertebrates as originally proposed by Cummins (1995) in this process. Thus "shredders" constitute the group responsible for the first stage in this process, the breakdown of CPOM to FPOM (fine particulate organic material). It is expected that the biomass of the different FFG's will vary with distance from the source of the stream or with increasing stream order (Vanotte et al. 1980 for more detail) Based on the tenets of this theory Buff Bay River, which is a fourth order stream, would be expected to show equal numbers of shredders and collectors in the upper section of the river, followed by equivalent numbers of collectors and scrapers in the lower river section. The results based on percentage of taxa in FFG's indicate a dominance of collectors at all sites followed by predators except at site five, where many of the insect taxa are absent. Scrapers and shredders are approximately equivalent at all sites with the percentage of the latter increasing slightly in the downstream sites. This pattern is substantiated when considering number of individuals with the percentage of shredders being higher and scrapers lower, at site one.
While the RCC model is quite well validated in relation to temperate streams, there is less support for its applicability in tropical rivers (Boulton et al. 2008). Numerous studies have demonstrated the lack of a cadre of shredders in tropical streams (Rosemond et al. 1998, Bass 2003, Dobson et al. 2002). It has been proposed that leaf breakdown in such streams is primarily achieved by microbial action which in turn is magnified by a faster microbial decomposition rate in tropical streams due to higher water temperatures (Irons et al. 1994). Other explanations offered are that the presence of secondary compounds in the leaves of tropical trees makes them unpalatable to shredding invertebrates (Wantzen et al. 2002); that most of the allochthonous input in tropical streams is in the form of FPOM which is directly ingested by collectors (Yule \& Pearson 1996); or that shredders in tropical streams are present but somehow overlooked. Dobson (2004) noted that freshwater crabs, which were important shredders in African streams, made up $80 \%$ of the invertebrate biomass but were frequently overlooked by traditional sampling techniques used for benthic macroinvertebrates. The importance of decapod crustaceans, particularly freshwater crabs (Moss 2005), and atyid and palaemonid shrimps (March et al. 2001), in the shredding process has been widely recognised. Wantzen \&Wagner (2006) suggested that shredders, while largely under-represented in tropical streams, might be either facultative specialists due to the low and sporadic input of CPOM, which switch to shredding when the resource becomes abundant, or localized specialists which are restricted to only a few sites that provide a permanent food resource.

Another factor contributing to the scarcity of shredders is the absence of the stoneflies (Plecoptera) from Jamaican streams (Vinson \& Hawkins 2003). Members of this order are frequently identified as a major component of the shredder feeding guild (Allan \& Castillo 2007). Based on the findings presented here, we find only limited support for the codominance of the shredder FFG in the upper reaches of Buff Bay River. The slightly higher 
representation of shredders at site one is due to the exclusive occurrence of freshwater crabs at this site, but decapod shrimps were not captured in large numbers at the top of the river nor was this FFG present in equivalent numbers to the collector guild. Predominance of collector-gatherers throughout the river has been reported in other studies of neotropical streams (Tomanova et al. 2006).

This paper represents the first published detailed description of the benthic macroinvertebrate fauna along the length of a typical North coast Jamaican stream. We conclude that while there is some minor variation in the composition of the fauna of the Buff Bay River, the characteristics of the community do not conform to either of the models outlined above and that any differences in composition are a response to local conditions within the river system. The findings substantiate the position, expressed by other authors, that the shredder FFG is less predominant in tropical streams. Short, low order streams, such as Buff Bay River, typical of island systems like Jamaica, may be characterised by limited community complexity and a broad heterogeneity of composition along their length.

The direction of future research on Jamaican freshwater systems needs to accommodate the socioeconomic changes occurring in the country. A detailed study of the microhabitat requirements of key invertebrate species and their role in the community, in line with taxonomic revision, would seem to be fruitful lines to follow which would allow monitoring of the effects of mounting anthropogenic change on freshwater systems.

\section{RESUMEN}

La fauna bentónica de macroinvertebrados juega un papel importante en los ecosistemas fluviales, especialmente los de las islas tropicales. En vista de que hay poca información disponible para los ríos de Jamaica, presentamos la composición de la fauna bentónica de la bahía riverina Buff, en la costa norte de Jamaica. Para ello, recolectamos un total de 14 muestras en cinco sitios, mediante el uso de redes de golpe y trampa Surber, entre mayo 1997 y octubre 1998. También se examinó la aplicabilidad del modelo de subdivisión de ríos ritrón/potamón y algunas de las premisas del concepto de Río como un Continuo, en relación con la distribución de los táxones de invertebrados. Los resultados mostraron un total de 38 táxones de invertebrados identificados, hay un grupo de táxones dominantes, compuesto principalmente por los estadios inmaduros de insectos, que se presentaron en todos los sitios. Dos características notables del río fueron la ausencia de una fauna de potamón verdadera y la escasa representación del grupo funcional alimenticio triturador en la comunidad. Llegamos a la conclusión de que, si bien hay una variación de menor importancia en la composición de la fauna de macroinvertebrados bentónicos entre los sitios, esto fue una respuesta a las condiciones locales dentro del sistema fluvial y las características de la comunidad que no se ajusta a ninguno de los modelos. Este estudio representa la primera publicación de una descripción longitudinal de la fauna bentónica de macroinvertebrados de un sistema fluvial de Jamaica.

Palabras clave: agua dulce, invertebrados, composición de comunidades, zonación longitudinal, concepto de Río como un Continuo, Caribe.

\section{REFERENCES}

Allan, J.D. \& M.M. Castillo. 2007. Stream ecology. Structure and function of running waters. Springer, The Netherlands.

Barnish, G. 1984. The freshwater shrimps of St. Lucia, West Indies (Decapoda: Natantia). Crustaceana 47: 314-320.

Bass, D. 2003. A comparison of freshwater macroinvertebrate communities on small Caribbean islands. BioScience 53: 1094-1110.

Baptista, D.F., F.M. Dorvillé, D.F. Buss \& J.L. Nessiamian. 2001. Spatial and temporal organization of aquatic insect assemblages in the longitudinal gradient of a tropical river. Rev. Bras. Biol. 61: 295-304.

Boon, P.J., B.P. Jupp \& D.G. Lee. 1986. The benthic ecology of rivers in the Blue Mountains (Jamaica) prior to construction of a water regulation scheme. Arch. Hydrobiol. 74: 315-355.

Boulton, A.J., L. Boyero, A.P. Covich, M. Dobson, S. Lake \& M. Pearson. 2008. Are tropical streams different from temperate streams?, p. 257-284. In D. Dudgeon (ed.). Tropical Stream Ecology. Elsevier, Amsterdam, The Netherlands.

Buskirk, R.E. 1985. Zoogeographic patterns and tectonic history of Jamaica and the northern Caribbean. J. Biogeogr. 12: 445-461. 
Chace, F.A. \& H.H. Hobbs. 1969. The freshwater and terrestrial crustaceans of the West Indies with special reference to Dominica. Bull. U.S. Natl. Mus. 292: $1-258$.

Chaniotis, B.N., J.M. Butler, F.F. Ferguson \& W.R. Jobin. 1980. Thermal tolerance, desiccation and humidity reactions of Thiara (Tarebia) granifera mauiensis (Gastropoda: Thiaridae) host of the Asiatic lung fluke disease. Carib. J. Sci. 16: 91-93.

Comer, J.B. 1974. Genesis of Jamaican bauxite. Econ. Geol. 69: 1251-1264.

Covich, A.P. 1988. Geographical and historical comparisons of Neotropical streams: biotic diversity and detrital processing in highly variable habitats. J. N. Am. Benthol. Soc. 7: 361-386.

Cummins, K.W. 1995. Invertebrates, p. 234-250. In P. Calow \& G.E. Petts (eds.). The Rivers Handbook. Blackwell, USA.

Dobson, M. 2004. Freshwater crabs in Africa. Freshwater Forum 21: 3-26.

Dobson, M., A. Magana, J.M. Mathooko \& F.K. Nedegwa. 2002. Detritivores in Kenyan highland streams; more evidence for the paucity of shredders in the tropics? Freshwat. Biol. 47: 909-919.

Edmunds, G.F. 1984. Ephemeroptera, p. 242-248. In S.H. Hurlbert \& A. Villalobos-Figueroa (eds.). Aquatic Biota of Mexico, Central America and the West Indies. San Diego State University, California, USA.

Graca, M.A., C. Cressa, M.G. Gessner, M.J. Feto, K.A. Callies \& C. Barrios. 2001. Food quality, feeding preferences, survival and shredders from temperate and tropical streams. Freshwat. Biol. 45: 947-957.

Gonzalez-Lazo, D. \& S.S. Salves. 2007. Description of a new species of Fallcecon from Cuba, and redescription of F. longicollis (Ephemeroptera: Baetidae). Zootaxa 1583: 51-57.

Gupta, A. 1975. Stream characteristics in eastern Jamaica, anenvironment of seasonal flow and large floods. Am. J. Sci. 275: 825-847.

Harrison, A.D. \& J.J. Rankin. 1976. Hydrobiological studies of Eastern Lesser Antillean Islands. II St. Vincent: freshwater fauna, its distribution, tropical river zonation and biogeography. Arch. Hydrobiol. 50: $175-211$

Hartnoll, R.G. 1964. The freshwater grapsid crabs of Jamaica. Proc. Linn. Soc. Lond. 175: 145-169.
Hunte, W. 1978. The distribution of freshwater shrimps. Zool. J. Lin. Soc. 64: 135-150.

Hunte, W. 1979. The complete larval development of the freshwater shrimp Micratya poeyi (Guerin-Meneville) reared in the laboratory (Decapoda, Atyidae). Crustaceana 5: 151-168.

Hynes, H.B.N. 1971. Zonation of the invertebrate fauna of a West Indian stream. Hydrobiologia 38: 1-8.

Hyslop, E.J. 2003. Additions to the freshwater malacofauna of Jamaica. Rev. Biol. Trop. 51: 262-263.

Illies, J. \& L. Botosaneanu. 1963. Problemes et methods de la classification et de la zonation ecologique des eaux courantes, considerees surtout du point de vue faunistique. Mitt. Internat.Verein. Limnol. 12: 1-57.

Irons, J.G., M.W. Oswood, R.J. Stout \& C.M. Pringle. 1994. Latitudinal patterns in leaf litter breakdown: is temperature really important? Freshwat. Biol. 32: 401-411.

Jacobsen, D., R. Schultz \& A. Encalada. 1997. Structure and diversity of invertebrate assemblages: the influence of temperature with altitude and latitude. Freshwat. Biol. 38: 247-261.

Jackson, J.K. \& B.W. Sweeney. 1995. Research in tropical streams and rivers: introduction to a series of papers. J.N. Am. Benthol. Soc. 14: 2-4.

Lake, P., E.S.G. Schreiber, B.J. Milne \& R.G. Pearson. 1994. Species richness over time with stream size and latitude. Ver. Int. Verein. Limnol. 25: 1822-1826.

March, J.G., J.P. Benstead, C.M. Pringle \& M.W. Ruebel. 2001. Linking shrimp assemblages with rates of detrital processing along an elevational gradient in a tropical stream. Can. J. Fish. Aquat. Sci. 58: 470-478.

March, J.G. \& C.M. Pringle. 2003. Food web structure and basal resource utilization along a tropical island stream continuum, Puerto Rico. Biotropica 35: 84-93.

Merrit, R.W. \& K.W. Cummins. 1996. An Introduction to the Aquatic Insects of North America. Kendall/Hunt, Iowa, USA.

Moss, B. 2005. Rapid shredding of leaves by crabs in a tropical African stream. Verh. Int. Verein. Limnol. 29: $147-150$.

Moss, B. 2010. Ecology of freshwaters. A view for the twentieth century. Wiley-Blackwell, Oxford, USA. 
Peters, W.L. 1971. A revision of the Leptophlebiidae of the West Indies (Ephemeroptera). Smith. Contrib. Zool. 62: 1-48.

Pointier, J.P. 2001. Invading freshwater snails and biological control in Martinique island, French West Indies. Mem. Instit. Osw. Cruz 96: 67-74.

Porter, A.R.D., T.A. Jackson \& E. Robinson. 1982. Minerals and rocks of Jamaica. Kingston, Jamaica.

Rosemond, A.D., C.M. Pringle \& A. Ramirez. 1998. Macroconsumer effects on insect detritivores and detritus processing in a tropical stream. Freshwater Biol. 39: 513-523.

Rundle, S.D., A. Jenkins \& S.J. Ormerod. 1993. Macroinvertebrate communities in streams in the Himalayas, Nepal. Freshwat. Biol. 30: 169-180.

Schubart, C.D., J. Reimer \& R. Diesel.1998. Morphological and molecular evidence for a new endemic freshwater crab Sesarma ayatum sp. n. (Grapsidae; Sesarminae) from eastern Jamaica. Zool. Scrip. 7: 373-380.

Sheldon, A.L. \& R.A. Haick. 1981. Habitat selection and association of streaminsects: a multivariate analysis. Freshwat. Biol. 11: 395-403.

Starmuhlner, F. 1984. Occurrence, longitudinal distribution and geographical range of the fresh- and brackish water molluscs of the lesser Antillean islands (Guadeloupe, Dominica, Martinique). Soosiana 12: 83-102.

Statzner, R.B., J.A. Gore \& V.H. Resh. 1988. Hydraulic stream ecology: observed patterns and potential applications. J. N. Amer. Benthol. Soc. 7: 307-360.

Statzner, R.B. \& B. Higler. 1985. Questions and comments on the river continuum concept. Can. J. Fish. Aquat. Sci. 42: 1038-1044.
Stout, J. \& J. Vandermeer. 1975. Comparison of species richness for stream inhabiting insects in tropical and mid-latitude streams. Am. Nat. 109: 263-280.

Thompson, F.G. 2004. The freshwater snails of Florida. A manual for identification. University of Florida, Gainesville, USA.

Thorpe, J.H. \& A.H. Covich. 2001. Ecology and Classification of North American Freshwater invertebrates. Academic, San Diego, USA.

Tomanova, S., E. Goitia \& J. Helesic. 2006. Trophic levels and functional feeding groups of macroinvertebrates in neotropical streams. Hydrobiologia 556: 252-264.

Turner, D., D.D.Williams \& M. Alkins-Koo. 2008 Longitudinal changes in benthic community composition in four neotropical streams. Carib. J. Sci. 44: 380-394.

Vanotte, R.L., G.W. Minshall, K.W. Cummins, J.R. Sedeli \& C.E. Cushing. 1980. The river continuum concept. Can. J. Fish. Aquat. Sci. 37: 130-137.

Vinson, M.R. \& C.P. Hawkins. 2003. Broad scale geographical patterns in local stream insect genera richness. Ecography 26: 751-767.

Wantzen, K.M., R. Wagner, R. Suetfield \& W.J. Junk. 2002. How do plant-herbivore interactions influence coarse detritus processing by shredders in aquatic systems at different latitudes? Ver. Int. Verein. Limnol. 8: 815-821.

Wantzen, K.M. \& R. Wagner. 2006. Detritus processing by shredders: a tropical-temperate comparison. J. N. Amer. Benthol. Soc. 25: 214-230.

Yule, C.M. \& R.G. Pearson. 1996. A seasonality of invertebrates in a tropical stream in Bougainville Island, Papua New Guinea. Arch. Hydrobiol. 137: 95-117. 
